\title{
EEG SENSORIMOTOR RHYTHMS IN CHILDREN WITH AUTISM SPECTRUM DISORDERS
}

\author{
Kaida AI $\otimes$, Eismont EV, Mikhailova AA, Pavlenko VB
}

Vernandsky Crimean Federal University, Simferopol, Russia

One of the currently assumed causes of impaired social interaction exhibited by children with autism spectrum disorders (ASD) is dysfunction of the mirror neuron system (MNS), which is responsible for imitation, understanding the intentions and emotions of other people. Desynchronization of sensorimotor rhythms is considered to be the indicator of MNS activation. This study aimed to analyze the specific patterns of reactivity of the $\mu$-rhythm in an individually determined frequency range and $\beta$-rhythm on the EEG in children with ASD during independent movements, observation, imitation and auditory perception of similar movements performed by another person. The data collected were compared to those describing normally developing children. The study involved right-handed children with ASD aged 5-10 $(n=10)$ and normally developing children $(n=10)$. In the independent movements exercise, $\beta$-rhythm desynchronization was more pronounced in children with ASD, with difference becoming significant in the P4 locus $(p=0.03)$. In the movements imitation exercise, the groups showed significant differences in the EEG $\mu$-rhythm in the locus C3 $(p=0.03$ ). Auditory perception of movements revealed significant differences in the ranges of both $\mu$-rhythm (loci F3 and Fz $(p=0.02), F 4(p=0.04), C z(p=0.009))$ and $\beta$-rhythm (loci Fz $(p=0.01), F 4(p=0.02))$. In these situations, children with ASD exhibited synchronization of sensorimotor rhythms, while normally developing children showed desynchronization. The assumption is that the specific patterns revealed are the consequences of disruption of functions of MNS and anti-mirror system. The data obtained can be used in development of EEG biofeedback training protocols for children with ASD.

Keywords: children, autism, EEG, mu-rhythm, beta-rhythm, mirror neuron system

Funding: the study received a grant \#VG08/2020 supported by Vernadsky Crimean Federal University.

Author contribution: Kaida Al — data collection and processing, article authoring; Eismont EV — research planning, data collection, article authoring; Mikhailova AA — data processing, article authoring; Pavlenko VB — research planning, article authoring.

Compliance with ethical standards: the study was approved by the Vernandsky Crimean Federal University ethics committee (Minutes \#6 of June 04, 2020). Parents of the children submitted the informed consent forms allowing their children to participate in the experiment.

$\checkmark$ Correspondence should be addressed: Anna I. Kaida

Angarskaya, 38, Simferopol, 295001; kaydaanna@gmail.com

Received: 19.08.2020 Accepted: 11.09.2020 Published online: 22.09.2020

DOI: $10.24075 /$ brsmu.2020.055

\section{СЕНСОМОТОРНЫЕ РИТМЫ ЭЭГ У ДЕТЕЙ С РАССТРОЙСТВАМИ АУТИСТИЧЕСКОГО СПЕКТРА}

А. И. Кайда ${ }^{凶}$, Е. В. Эйсмонт, А. А. Михайлова, В. Б. Павленко

Крымский федеральный университет имени В. И. Вернадского, Симферополь, Россия

\begin{abstract}
В настоящее время одной из причин нарушения социального взаимодействия у детей с расстройствами аутистического спектра (РАС) считают дисфункцию системы зеркальных нейронов (СЗН), ответственной за подражание, понимание намерений и эмоций других людей. Индикаторами активации СЗН принято считать десинхронизацию сенсомоторных ритмов. Целью работы было проанализировать особенности реактивности н-ритма в индивидуально определенном частотном диапазоне и $\beta$-ритма ЭЭГ у детей с РАС, по сравнению с нормально развивающимися детьми, при осуществлении самостоятельных движений, наблюдении, имитации и слуховом восприятии аналогичных движений, выполняемых другим человеком. В исследовании приняли участие дети-правши 5-10 лет с PAC $(n=10)$ и нормально развивающиеся $(n=10)$. При наблюдении движений у детей с РАС десинхронизация $\beta$-ритма была более выражена, различия достигали уровня статистической значимости в локусе $\mathrm{P} 4$ ( $p=0,03)$. В ситуации имитации движений значимые различия в индексах реактивности $\mu$-ритма ЭЭГ выявлены в отведении С 3 ( $p=0,03)$. При слуховом восприятии движений значимые различия зарегистрированы в диапазоне как $\mu$-ритма (локусы F3 и Fz (p=0,02), F4 ( $p=0,04), \mathrm{Cz}(p=0,009)$ ), так и $\beta$-ритма (локусы Fz (p=0,01), F4 $(p=0,02))$. В данных ситуациях у детей с РАС происходила синхронизация сенсомоторных ритмов, в отличие от нормально развивающихся детей, демонстрировавших десинхронизацию. Предполагается, что обнаруженные особенности являются следствием нарушения функционирования СЗН и антизеркальной системы мозга. Полученные данные могут быть использованы при разработке протоколов тренингов биологической обратной связи по ЭЭГ для детей с РАС.
\end{abstract}

Ключевые слова: дети, аутизм, ЭЭГ, $\mu$-ритм, $\beta$-ритм, система зеркальных нейронов

Финансирование: исследование выполнено в рамках поддержанного федеральным государственным автономным образовательным учреждением высшего образования «Крымский федеральный университет имени В. И. Вернадского» гранта № ВГо8/2020.

Вклад авторов: А. И. Кайда - набор и обработка данных, написание статьи; Е. В. Эйсмонт — планирование исследования, набор данных, написание статьи; А. А. Михайлова - обработка данных, написание статьи; В. Б. Павленко - планирование исследования, написание статьи.

Соблюдение этических стандартов: исследование одобрено этическим комитетом Крымского федерального университета имени В. И. Вернадского (протокол № 6 от 04 июня 2020 г.). Получено добровольное информированное согласие родителей на участие детей в эксперименте.

$\triangle$ Для корреспонденции: Анна Ивановна Кайда

ул. Ангарская, д. 38, г. Симферополь, 295001; kaydaanna@gmail.com

Статья получена: 19.08.2020 Статья принята к печати: 11.09.2020 Опубликована онлайн: 22.09.2020

DOI: 10.24075 /vrgmu.2020.055

Autism spectrum disorders (ASD) are a group of complex developmental disorders heterogeneous in their symptoms and signs. The distinctive manifestations of such disorders are hampered social interactions, difficulties with language learning, limited repetitive behavior. ASD also manifest in increased nervousness, embarrassment, eye contact avoidance [1]. The prevalence of autism in the world varies depending on the diagnostic criteria, country, region [2]. On average, according to the World Health Organization, 1 in 160 children worldwide has ASD.

It should be noted that deficient social skills is one of the main and lifelong signs of this disorder. Numerous research 
efforts report connection between social interaction difficulties experienced by autistic children and dysfunction of brain regions that are part of the mirror neuron system (MNS) [3]. Mirror neurons were originally thought to be involved in perception and understanding of actions, but they also play an important role in higher-order cognitive processes such as imitation, empathy, language and speech acquisition. This system also determines understanding of someone else's consciousness (theory of mind), that is, a person's ability to draw conclusions about intentions, desires and emotions that direct actions of another person [4]. It was established that impairment of this ability in children with ASD leads to difficulties in social interaction [5].

EEG study of MNS makes use of such parameters as reactivity of sensorimotor $\mu$ - and $\beta$-rhythms [6]. It was established that the amplitude of sensorimotor rhythms (SMR) decreases during performance, observation, imitation, mental representation and auditory perception of movements [7].

It is known that children with ASD exhibit $\mu$-rhythm suppression when performing independent movements, but it is absent or weak when they observe similar actions performed by another person [8, 9]. Adult volunteers with high scores on the Autism Spectrum Quotient (AQ) scale also showed weaker $\mu$-rhythm desynchronization when observing actions, compared to people scoring low on this scale [10]. In another study, adults with high scores on the Autism Spectrum Quotient scale did not show desynchronization in either $\mu$ - or $\beta$-ranges when observing actions [11]. Thus, low level of MNS activation indicated by the weak desynchronization of SMR can be the main reason behind the observed deficiency of empathy and imitation in people with ASD [8], which is further confirmed by a research effort that revealed a connection between impairment of the main MNS regions in the left hemisphere and imitation disorders [12]. However, a number of studies reported no significant differences in the $\mu$-rhythm reactivity in children and adults with ASD compared to their healthy peers [13]. The results of a recent study indicate that, although $\mu$-rhythm suppression in children with ASD differs from that shown by the control group children when observing specific types of actions, the difference was not significant overall. Nevertheless, authors note that children with ASD spent more time recognizing actions, i.e. their reaction was slower [14]. Thus, current experimental evidence of $\mu$-rhythm reactivity specificity in children with ASD is mixed, and only a few researchers have studied sensorimotor $\beta$-rhythm in such children. Besides, SMR reactivity in children with ASD is mostly studied with the focus on movement observation and execution. Therefore, it is of particular interest to study such rhythms in connection with other activities, such as imitation and auditory recognition of actions.

EEG biofeedback training for children with ASD focuses on developing the $\mu$-rhythm modulation capability [15]. Biofeedback therapy yielded better $\mu$-rhythm desynchronization in autistic children when observing and executing actions. Moreover, this therapy improved social behavior of such children: they were able to better recognize emotions and actions of other people $[16,17]$.

However, previous research efforts did not consider individual ranges of $\mu$-rhythm reactivity in the context of examining $E E G$ of children with ASD and giving them biofeedback therapy. It is known that the degree of desynchronization of $\mu$-rhythm can be assessed incorrectly because of the overlapping occipital $\alpha$-rhythm, which has a close frequency range [13]. In this connection, the recommendation is to determine the individual $\mu$-rhythm band when the child makes independent movements.

In view of the aforesaid, this study aimed to analyze the specific patterns of $\mu$-rhythm reactivity in an individually determined frequency range and $\beta$-rhythm on the EEG in children with ASD during independent movements (of computer mouse), observation, imitation and auditory perception of similar movements performed by another person.

\section{METHODS}

\section{Sample characteristics}

The study was carried out at the Scientific Equipment Shared Use Center "Experimental Physiology and Biophysics" of Vernandsky Crimean Federal University.

The study involved 20 right-handed children aged 5 to 10 (mean age $7.4 \pm 0.5$ years), of which 10 children have ASD ( 9 boys and 1 girl) and 10 are normally developing children of matching age and gender (control group). The ASD group included children diagnosed with "childhood autism" (F84.0 in ICD-10) or "autism spectrum disorder with intellectual disability and functional language impairment" (6A02.3 in ICD-11). The criteria for inclusion in control group were a sufficient level of cognitive development (IQ 90 to 120 scored in WPPSI and WISC variants of the Wechsler scale) and absence of chronic diseases of the nervous system. Inclusion criteria for both groups: normal (or corrected to normal) levels of vision and hearing; preference for the right hand in computer mouse operation.

\section{EEG registration}

We used a Neuron-Spectrum-3 (Neurosoft; Russia) 19 channel electroencephalograph to register EEG. EEG potentials were leaded monopolarly, following the 10-20 system. The areas of interest in this study were the frontal, central and parietal regions of the neocortex (loci F3, F4, Fz, C3, C4, Cz, P3, P4, Pz). Joint contacts fixed to the earlobes served as a reference electrode. The cutoff frequencies of the high- and low-frequency filters were 1.5 and $35 \mathrm{~Hz}$, respectively, and the frequency of EEG signals digitization was $250 \mathrm{~Hz}$.

We recorded EEG when children were performing a series of tasks lasting 30 seconds each. All children participating in the study understood the instructions and performed the tasks correctly. The sequence of tasks was as follows:

1) gaze fixation on the image of a computer mouse situated on the table in front of the experimenter (BACKGROUND 1);

2) independent movements with computer mouse at arbitrary speed (MOV.1);

3) gaze fixation on the image of a computer mouse situated on the table in front of the experimenter (BACKGROUND 2);

4) observation of movement of the experimenter's hand with a computer mouse (OBS);

5) gaze fixation on the image of a computer mouse situated on the table in front of the experimenter (BACKGROUND 3);

6) independent movements with computer mouse at arbitrary speed (MOV.2);

7) imitation of movements experimenter performs with computer mouse (IMIT);

8) the participant sits motionless with eyes closed (EC);

9) the participant hears (without prior instruction) characteristic sounds of a mouse rubbing against table surface when the experimenter moves the mouse (HEARING).

The data were processed using WinEEG software (Mitsar; Russia). The independent components method built into the application (with additional visual recording quality control interface) enabled removal of artifacts. EEG segments were subjected to fast Fourier transformation with 4 second epochs and $50 \%$ epoch overlap. 
Table 1. Results of analysis of variance of differences in the $\mu$-rhythm reactivity, children developing normally children with ASD

\begin{tabular}{|l|c|c|c|c|c|c|}
\hline \multirow{2}{*}{ Reactivity indices } & \multicolumn{2}{|c|}{ GROUP } & \multicolumn{2}{c|}{ LOCUS } & \multicolumn{2}{c|}{ GROUP $\times$ LOCUS } \\
\cline { 2 - 7 } & $F_{1.18}$ & $p$ & $F_{8.144}$ & $p$ & $F_{8.144}$ & $p$ \\
\hline RI MOV.1 & 0.04 & 0.84 & 4.64 & $<0.001$ & 1.85 & 0.07 \\
\hline RI OBS & 0.1 & 0.75 & 0.28 & 0.97 & 0.59 & 0.79 \\
\hline RI IMIT & 3.37 & 0.08 & 1.1 & 0.37 & 0.58 & 0.80 \\
\hline RI HEARING & 5.35 & 0.03 & 1.48 & 0.17 & 0.74 & 0.66 \\
\hline
\end{tabular}

For each stage, we calculated the mean EEG amplitude value in the range of $\mu$ - and $\beta$-rhythms $(15-25 \mathrm{~Hz})$. The $\mu$-rhythm range for each participant was determined individually, in lead C3, during independent movements of the right hand. The full frequency range of the $\mu$-rhythm $(6-13 \mathrm{~Hz})$ was divided into segments of $1 \mathrm{~Hz}$. Two adjacent segments with maximum desynchronization relative to the background were further considered as an individual frequency range [18]. We selected the $\beta$-rhythm range within the $15-25 \mathrm{~Hz}$ span, since this is where the sensorimotor areas' amplitude is suppressed during actions [19]. To normalize the distribution, the amplitude values were log transformed.

We used the generally accepted approach to sensorimotor rhythm reactivity index (RI) calculation. The formula is as follows: $\mathrm{RI}=\ln (\mathrm{B} / \mathrm{A})$, where $\mathrm{B}$ is the amplitude of the sensorimotor rhythm in the main situation and $A$ is the amplitude of the sensorimotor rhythm in the initial situation of comparison. For independent movement (MOV.1) and observation (OBS) situations, the sensorimotor rhythm $\mathrm{Rl}$ calculation factored in the gaze fixation situation (BACKGROUND 1 and BACKGROUND 2 , respectively). For the movements imitation situation (IMIT), RI was calculated against the preceding independent movements (MOV.2). HEARING situation had the RI determined against EC, calm wakefulness with closed eyes (GL). Positive Rl corresponded to synchronization of the sensorimotor rhythm, while its negative values corresponded to desynchronization.

\section{Statistical data processing}

We used STATISTICA 12.0 software (StatSoft Inc.; USA) to perform statistical analysis of the data obtained. The inter-group differences in frequency of the individually defined $\mu$-rhythm were assessed using the Mann-Whitney $U$ test. Repeated measures ANOVA enabled assessment of differences in the amplitude and reactivity indices of sensorimotor rhythms. We also assessed the influence of GROUP, an external participantrelated factor (two levels: children with ASD and the control group) and LOCUS, and internal participant-related factor (nine EEG leads) relying on the $2 \times 9$ pattern. F-distribution estimation, or the method of a priori contrasts, was used to calculate significance of differences in the analyzed parameters of sensorimotor rhythms relative to each of the nine EEG leads. Median and interquartile range allowed preparing description of distributions differing from the norm (extreme values of the individual $\mu$-rhythm range). For the normal data distribution cases (logarithmic values of amplitudes and reactivity indices), we used mean and standard error of the mean. The differences were considered statistically significant at $p<0.05$, but because of the small sample size we also included "unshaped" differences, i.e. those already visible but not yet fully formed $(p<0.10)$.

\section{RESULTS}

\section{Amplitude-frequency indicators of sensorimotor rhythms}

In the group of normally developing children, the lower limit median values for the individual $\mu$-rhythm range were $9.3 \mathrm{~Hz}$ $(8.5 ; 10)$. In the group of children with ASD, the lower limit median values for the individual $\mu$-rhythm range were $8.6 \mathrm{~Hz}$ $(7 ; 9.5)$. Despite the fact that the lower and upper limit medians of the individual $\mu$-rhythm in children with ASD are reduced, these differences between the groups, assessed with the Mann-Whitney $U$ test, did not reach the level of statistical significance $(p=0.57)$.

Analysis of variance of the sensorimotor rhythms amplitude peculiar to the independent movements situation did not reveal significant influences of the studied factors: $\mu$-rhythm - GROUP $\left(F_{1,18}=0.15 ; p=0.7\right)$ and LOCUS $\times$ GROUP $\left(F_{8,144}=0.75\right.$; $p=0.7), \beta$-rhythm $-\operatorname{GROUP}\left(F_{1,18}=0.35 ; p=0.6\right)$ and LOCUS

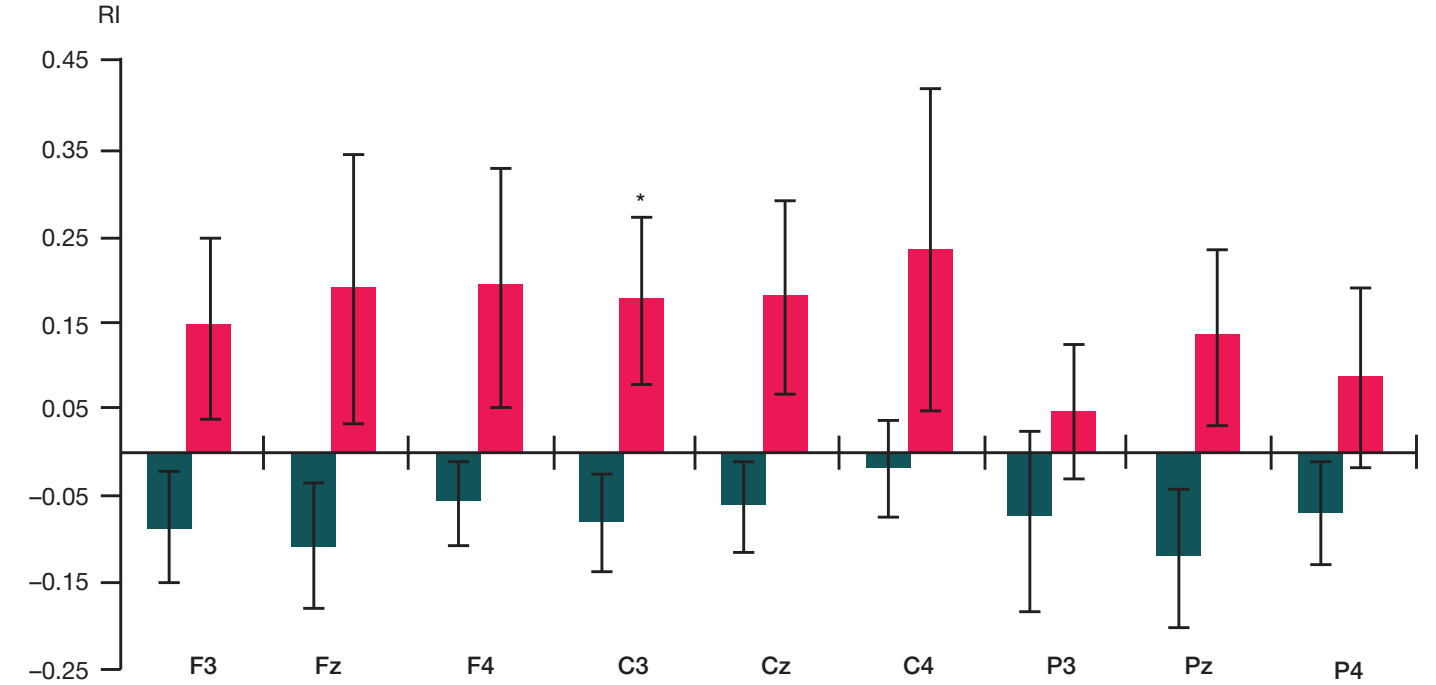

Fig. 1. EEG $\mu$-rhythm reactivity indices (RI), children with ASD (red bars) and normally developing children (green bars), imitation of the experimenter's movements. * $-p<0.05$ (significant differences in the $\mu$-rhythm reactivity indices) 
Table 2. Results of analysis of variance of differences in the $\beta$-rhythm reactivity, children developing normally children with ASD

\begin{tabular}{|l|c|c|c|c|c|c|}
\hline \multirow{2}{*}{ Reactivity indices } & \multicolumn{2}{|c|}{ GROUP } & \multicolumn{2}{c|}{ LOCUS } & \multicolumn{2}{c|}{ GROUP $\times$ LOCUS } \\
\cline { 2 - 7 } & $F_{1.18}$ & $p$ & $F_{8.144}$ & $p$ & $F_{8.144}$ & $p$ \\
\hline RI MOV.1 & 0.39 & 0.54 & 1.79 & 0.08 & 1.92 & 0.06 \\
\hline RI OBS & 1.81 & 0.2 & 0.68 & 0.71 & 2.73 & 0.01 \\
\hline RI IMIT & 2.93 & 0.1 & 1.01 & 0.43 & 0.4 & 0.92 \\
\hline RI HEARING & 4.09 & 0.06 & 0.77 & 0.63 & 0.73 & 0.66 \\
\hline
\end{tabular}

$\times \operatorname{GROUP}\left(F_{8.144}=0.72 ; p=0.7\right)$. In this experimental situation, only the LOCUS factor was found to have a significant effect on $\mu$-rhythms $\left(F_{8,144}=6.11 ; p<0.001\right)$ and $\beta$-rhythms $\left(F_{8,144}=\right.$ 14.09; $p<0.001)$. Thus, the sensorimotor rhythms amplitude did not differ significantly in children of the two groups when they performed independent movements.

\section{Specific patterns of EEG $\mu$-rhythm reactivity}

Table 1 shows the results of analysis of variance applied to the differences in the $\mu$-rhythm reactivity in children with and without ASD. For independent movements, we discovered a tendency of influence of the LOCUS $\times$ GROUP factors interaction. Further analysis by the method of a priori contrasts yielded no significant differences. No significant differences were found in the $\mu$-rhythm $\mathrm{Rl}$ in the movements observation situation, too.

In the experimenter movements imitation situation we have discovered influence exerted by the GROUP factor, although this influence was just a tendency. The method of a priori contrasts, applied, showed that the differences in EEG $\mu$-rhythm reactivity indices in two groups of children reached statistical significance in the central locus of the left hemisphere (C3: $p=0.03$; mean value and standard error of the mean for the control group: $-0.08 \pm 0.06$; for the RAS group: $0.18 \pm 0.1$ ) (Fig. 1). According to the diagrams presented below, $\mu$-rhythm synchronizes in all leads in children with ASD when they imitate movements of the experimenter, whereas their normally developing peers show $\mu$-rhythm desynchronization exclusively.

GROUP factor was also found to significantly influence auditory perception of familiar movements of a computer mouse. The EEG $\mu$-rhythm RI differences between the two groups of children reached statistical significance at the frontal loci and the central median lead (loci F3 ( $p=0.02$; control group: $-0.06 \pm 0.06$; ASD: $0.19 \pm 0.08)$ and Fz $(p=0.02$; control group: $-0.1 \pm 0.06$; ASD: $0.16 \pm 0.08)$, F4 $(p=0.04$; control group:
$-0.11 \pm 0.04 ;$ ASD: $0.16 \pm 0.11), \mathrm{Cz}(p=0.009$; control group: $-0.02 \pm 0.05$; ASD: $0.23 \pm 0.06)$ ) (Fig. 2). In this experimental situation, we have registered growth of the $\mu$-rhythm amplitude in all leads in children with ASD, whereas in the control group children it was mostly going down.

\section{Specific patterns of EEG $\beta$-rhythm reactivity}

Table 2 shows the results of analysis of variance applied to the differences in the $\beta$-rhythm reactivity in children of the two groups. Jointly, the LOCUS $\times$ GROUP factors tended to exert influence in the independent movements situation. The sensorimotor $\beta$-rhythm RI in children with and without ASD did not differ significantly in this situation.

The GROUP $\times$ LOCUS factors were found to exert significant influence in the observation situation, when the experimenter moved the mouse. The differences in $\beta$-rhythm reactivity between the groups of reached the statistical significance in the parietal locus of the right hemisphere (P4: $p=0.03$; control group: $0.03 \pm 0.03$; ASD: $0.16 \pm 0.08$ ) (Fig. 3). Children with ASD showed $\beta$-rhythm desynchronization, while most of the normally developing children exhibited synchronization, with the exception of the frontal regions where we registered a decrease in the amplitude of the studied rhythm.

The experimenter movements imitation situation did not reveal any significant $\beta$-rhythm $\mathrm{Rl}$ differences between the studied groups.

GROUP factor was discovered to have influence (tendency level) in the HEARING situation, with the participants perceiving sounds of movements of a computer mouse. The differences in EEG $\beta$-rhythm $\mathrm{Rl}$ between the groups reached statistical significance in the median frontal lead and in the frontal locus of the right hemisphere ( $F z$ loci $(p=0.01$; control group: $-0.05 \pm 0.03$; RAS: $0.08 \pm 0.04)$, F4 ( $p=0.02$; control group: $-0.09 \pm 0.03$; RAS: $0.08 \pm 0.06$ ) (Fig. 4). In the HEARING

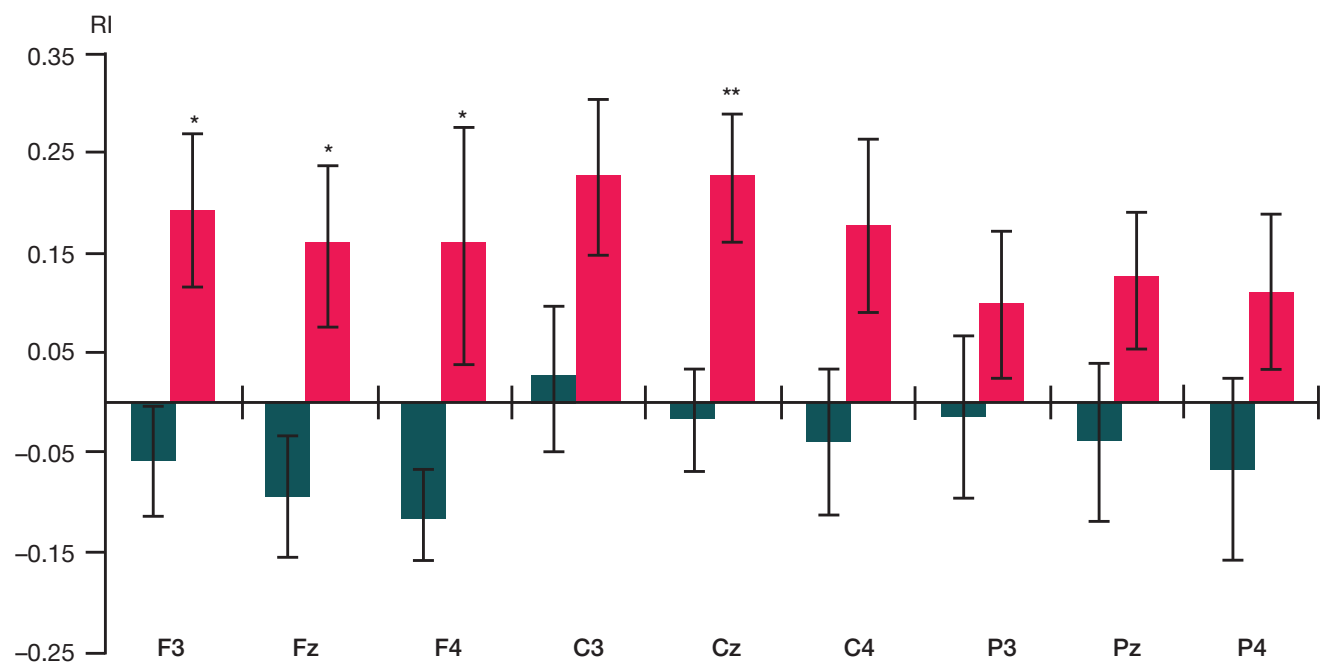

Fig. 2. EEG $\mu$-rhythm reactivity indices (RI), children with ASD (red bars) and normally developing children (green bars), auditory perception of movements. $-p<0.05 ;{ }^{* *}-p \leq 0.01$ (significant differences in the $\mu$-rhythm reactivity indices) 


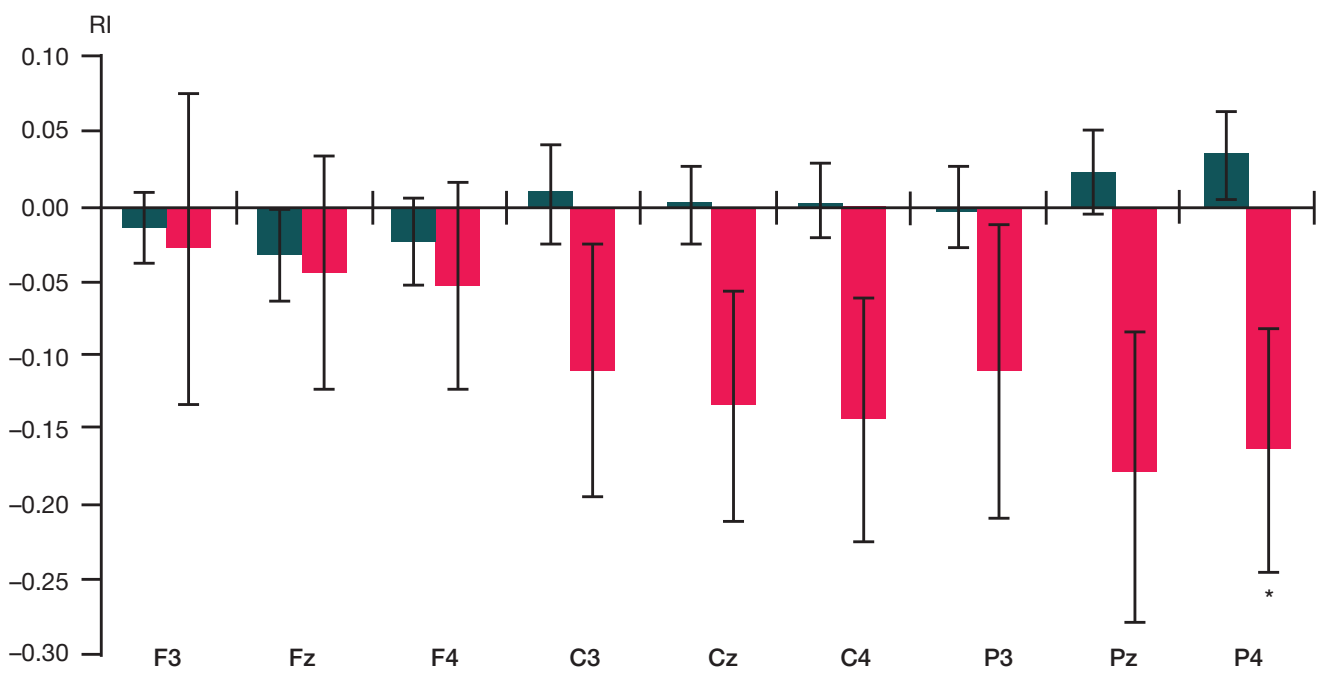

Fig. 3. EEG $\mu$-rhythm reactivity indices (RI), children with ASD (red bars) and normally developing children (green bars), observation of movements. Other symbols are same as those on Fig. 1

$\mathrm{RI}$

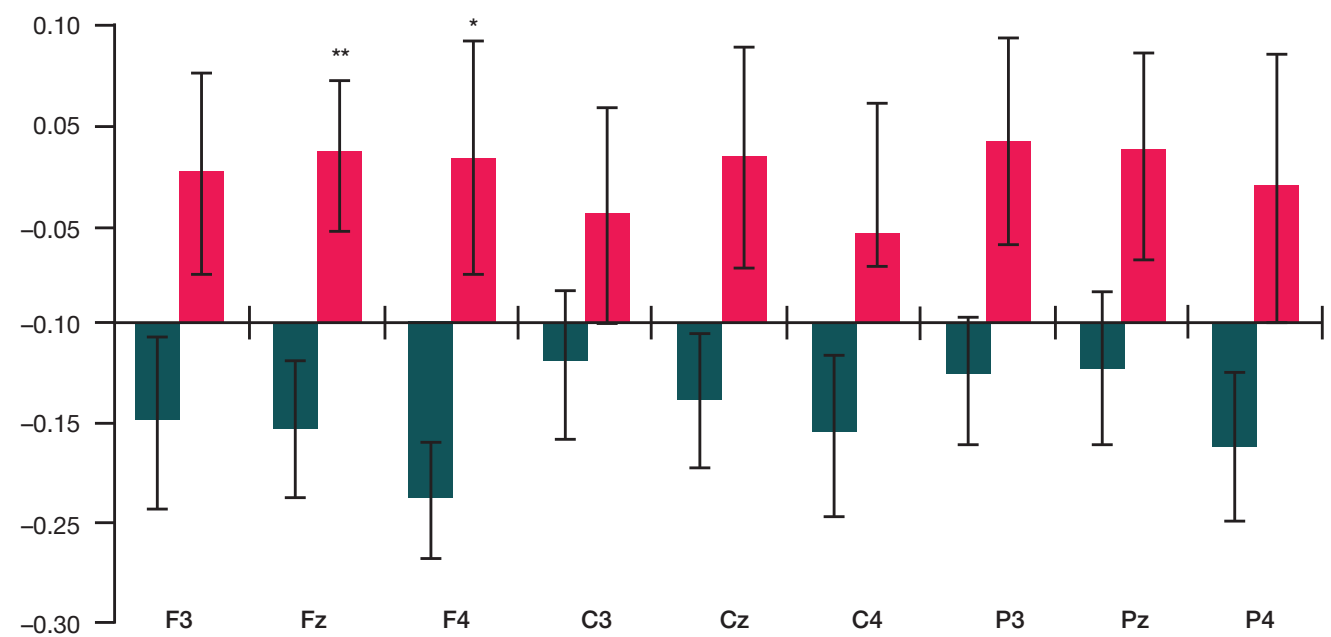

Fig. 4. EEG $\beta$-rhythm reactivity indices (RI), children with ASD (red bars) and normally developing children (green bars), auditory perception of movements. Other symbols are same as those on Fig. 2

situation children, with ASD exhibited synchronization of the $\beta$-rhythm in all leads, while the normally developing children had desynchronization of the studied rhythm.

\section{DISCUSSION}

The results of the present study indicate that the frequency of the $\mu$-rhythm in an individually determined range does not differ significantly in children with and without ASD. Previously, we have shown that the individually determined frequency of the $\mu$-rhythm does not depend on the age of children [21] on a sample of healthy 4-15 year-olds. However, both in the previous and in the present study, we revealed a wide variability of the lower and upper limits of the $\mu$-rhythm individual frequency range. In this connection, we recommend determining the child's individual frequency range before investigating specific patterns of his/her $\mu$-rhythm.

The independent movements exercise has shown that children with ASD have the same $\mu$ - and $\beta$-rhythm sensorimotor amplitudes as children that develop normally. Moreover, the analysis of SMR reactivity registered during performance of movements against motor rest condition has also uncovered no significant differences between the children of the studied groups. The data obtained confirm the results reported by other authors that revealed a normal reaction of $\mu$-rhythm desynchronization in children with ASD in the independent movements situation [8]. Thus, we can say that in children with this disorder, the somatosensory areas of the cortex that enable independent movements function normally.

Comparison of the SMR reactivity in children with ASD and the control group revealed differences in situations of observation, imitation and auditory perception of movements. In the movements imitation situation, children with autism had the $\mu$-rhythm synchronizing, while their normally developing peers have shown desynchronization. Earlier, it was established that people with autism have impaired imitative abilities [22]. A connection was also found between impairment of MNS of the left hemisphere and impairment of a person's ability to imitate actions [12]. Thus, the lack of desynchronization of the $\mu$-rhythm in children with ASD when imitating movements of another person may be associated with impaired MNS. Auditory perception with closed eyes (familiar movements of a computer mouse) was also not accompanied by desynchronization of sensorimotor $\mu$ - and $\beta$-rhythms in children with ASD. MNS is known to activate to sounds of familiar actions, which is accompanied with the SMR amplitude drop [23]. The results obtained once again confirm that children with ASD have MNS functions impaired. 
In the movements observation situation, children with ASD exhibited greater desynchronization of the $\beta$-rhythm in parietal EEG leads than the control group children. Studies have shown that autistic people lack desynchronization when observing actions per se [8, 9]. However, these research efforts focused on $\mu$-rhythm. The greater $\beta$-rhythm amplitude drop we have discovered in the movements observation situation may result from impaired functioning of the brain's anti-mirror system. It has been established that anti-mirror neurons detected during microelectrode examination of brain of epilepsy patients are triggered with movements and inhibited when such a patient observes movements of other people [24]. EEG shows inhibition of cortical neurons as $\beta$-rhythm synchronization [25]. A study involving adults registered $\beta$-rhythm synchronization when the participants observed emotionally neutral movements in a group of people with a low score on the Autism Coefficient scale, which the authors associate with the suppression of automatic copying of actions [10]. It was suggested that the anti-mirror system of the brain plays an important role in distinguishing between self and others' actions, as well as in preventing involuntary imitation [26]. Children with ASD have these functions impaired, which was reflected in our study as desynchronization of the $\beta$-rhythm registered when such children were observing actions. It can also be assumed that children with ASD spent more cognitive resources on incoming information processing, which was accompanied by a greater decrease in the $\beta$-range amplitude.

\section{References}

1. Lai MC, Lombardo MV, Baron-Cohen S. Autism. Lancet. 2014; 383 (9920): 896-910.

2. Makushkin EV, Makarov IV, Pashkovskiy VE. The prevalence of autism: genuine and imaginary. S.S. Korsakov Journal of Neurology and Psychiatry. 2019; 119 (2): 80-86. Russian.

3. Saffin JM, Tohid H. Walk like me, talk like me. The connection between mirror neurons and autism spectrum disorder. Neurosciences (Riyadh). 2016; 21 (2): 108-19.

4. Lebedeva NN, Zufman Al, Malcev Vu. Mirror neuron system as a key to learning, personality formation and understanding of another's mind. Uspehi fiziologicheskih nauk. 2017; 48 (4): 16-28. Russian.

5. Andreou M, Skrimpa V. Theory of mind deficits and neurophysiological operations in autism spectrum disorders: A review. Brain Sci. 2020; 10 (6): 393.

6. Fox NA, Bakermans-Kranenburg MJ, Yoo KH, Bowman LC, Cannon EN, Vanderwert RE, et al. Assessing human mirror activity with EEG mu rhythm: A meta-analysis. Psychol Bull. 2016; 142 (3): 291-313.

7. Ferrari PF, Rizzolatti G. New frontiers in mirror neurons research. NY: Oxford University Press, 2015; 408 p.

8. Oberman LM, Hubbard EM, McCleery JP, Altschuler EL, Ramachandran VS, Pineda JA. EEG evidence for mirror neuron dysfunction in autism spectrum disorders. Cognitive Brain Research. 2005; 24 (2): 190-98.

9. Martineau J, Cochin S, Magne R, Barthelemy C. Impaired cortical activation in autistic children: Is the mirror neuron system involved? International Journal of Psychophysiology. 2008; 68 (1): 35-40.

10. Siqi-Liu A, Harris AM, Atkinson AP, Reed CL. Dissociable processing of emotional and neutral body movements revealed by $\mu$-alpha and beta rhythms. Soc Cogn Affect Neurosci. 2018; 13 (12): 1269-79.

11. de Vega M, Padron I, Moreno IZ, García-Marco E, Domínguez A, Marrero $\mathrm{H}$, et al. Both the mirror and the affordance systems might be impaired in adults with high autistic traits. Evidence from EEG mu and beta rhythms. Autism Res. 2019; 12: 1032-42.

12. Binder E, Dovern A, Hesse MD, Ebke M, Karbe H, Saliger J, et al. Lesion evidence for a human mirror neuron system. Cortex. 2017;
The results of the present study indicate that in children with ASD, there is no desynchronization of SMR during imitation and auditory recognition of actions, and there is also no greater decrease in the amplitude of the $\beta$-rhythm when observing movements. The specific patterns revealed may point to disruptions in the functioning of the nervous system, MNS and the anti-mirror system of the brain in particular. The research results can be used to improve the effectiveness of EEG-BFB trainings with children with ASD.

\section{CONCLUSIONS}

The study revealed specific patterns of SMR reactivity in children with ASD. Compared to the control group, children with ASD had EEG $\mu$ - and $\beta$-rhythms syncronizing when in the imitation and auditory recognition situations, which may indicate a dysfunction of the MNS that enables imitation and normal social interaction. When observing movements of children with ASD, we registered a greater decrease in the amplitude of the sensorimotor $\beta$-rhythm, which may be associated with a dysfunction of the activity of the antimirror system of the brain. The results obtained highlight the need to study reactivity of both the sensorimotor $\mu$-rhythm and $\beta$-rhythm in children with ASD. The revealed patterns can be used to help children with ASD, for example, using biofeedback trainings to improve EEG sensorimotor rhythms characteristics.

\section{0: $125-37$}

13. Hobson HM, Bishop DVM. The interpretation of mu suppression as an index of mirror neuron activity: past, present and future. Review R Soc Open Sci. 2017; 4 (3): 160662.

14. Sotoodeh MS, Taheri-Torbati H, Sohrabi M, Ghoshuni M. Perception of biological motions is preserved in people with autism spectrum disorder: electrophysiological and behavioural evidences. J Intellect Disabil Res. 2019; 63 (1): 72-84.

15. Pineda JA, Carrasco K, Datko M, Pillen S, Schalles M. Neurofeedback training produces normalization in behavioural and electrophysiological measures of high-functioning autism. Philos Trans R Soc Lond B Biol Sci. 2014; 369 (1644): 20130183.

16. Friedrich EVC, Sivanathan A, Lim T, Suttie N, Louchart S, Pillen S, et al. An effective neurofeedback intervention to improve social interactions in children with autism spectrum disorder. J Autism Dev Disord. 2015; 45: 4084-100.

17. Datko M, Pineda JA, Muller RA. Positive effects of neurofeedback on autism symptoms correlate with brain activation during imitation and observation. Eur J Neurosci. 2018; 47 (6): 579-91.

18. Mahin SA, Kaida Al, Eismont EV, Mikhailova AA, Pavlenko VB; FGAOU VO "Krymskij federal'nyj universitet imeni V.I. Vernadskogo", patentoobladatel'. Sposob opredelenija individual'nogo chastotnogo diapazona mju-ritma JeJeG. Patent RF \# 2702728. 09.10.2019. Russian.

19. Simon S, Mukamel R. Power modulation of electroencephalogram mu and beta frequency depends on perceived level of observed actions. Brain Behav. 2016; 6 (8): e00494

20. Raymaekers R, Wiersema JR, Roeyers H. EEG study of the mirror neuron system in children with high functioning autism. Brain research. 2009; 1304: 113-21.

21. Kaida Al, Mikhailova AA, Eismont EV, Dzhapparova LL, Pavlenko VB. EEG $\mu$-rhythm reactivity in children during imitation of biological and non-biological motion. [published online ahead of print, 2020.04.16]. Bulletin of RSMU. 2020. DOI: 10.24075/ brsmu.2020.019.

22. Bernier R, Dawson G, Webb S, Murias M. EEG mu rhythm and imitation impairments in individuals with autism spectrum disorder. 
Brain and Cognition. 2007; 64 (3): 228-37.

23. Pineda JA, Grichanik M, Williams V, Trieu M, Chang H, Keysers C. EEG sensorimotor correlates of translating sounds into actions. Front Neurosci. 2013; 7: 203.

24. Mukamel R, Ekstrom AD, Kaplan J, lacoboni M, Fried I. Singleneuron responses in humans during execution and observation of actions. Current Biology. 2010; 20 (8): 750-56.

25. Kropotov YuD. Kolichestvennaja JeJeG, kognitivnye vyzvannye potencialy mozga cheloveka i nejroterapija. Doneck: Izdatel' Zaslavkij Ju.A., 2010; 506 s. Russian.

26. Rizzolatti $G$, Sinigaglia C. Mirrors in the brain: how our minds share actions and emotions. Oxford University Press, 2008; 242 p.

\section{Литература}

1. Lai MC, Lombardo MV, Baron-Cohen S. Autism. Lancet. 2014; 383 (9920): 896-910.

2. Макушкин Е. В., Макаров И. В., Пашковский В. Э. Распространенность аутизма: подлинная и мнимая. Журнал неврологии и психиатрии им. С. С. Корсакова. 2019; 119 (2): 80-86.

3. Saffin JM, Tohid H. Walk like me, talk like me. The connection between mirror neurons and autism spectrum disorder. Neurosciences (Riyadh). 2016; 21 (2): 108-19.

4. Лебедева Н. Н., Зуфрман А. И., Мальцев В. Ю. Система зеркальных нейронов мозга: ключ к обучению, формированию личности и пониманию чужого сознания. Успехи физиологических наук. 2017; 48 (4): 16-28.

5. Andreou M, Skrimpa V. Theory of mind deficits and neurophysiological operations in autism spectrum disorders: A review. Brain Sci. 2020; 10 (6): 393.

6. Fox NA, Bakermans-Kranenburg MJ, Yoo KH, Bowman LC, Cannon EN, Vanderwert RE, et al. Assessing human mirror activity with EEG mu rhythm: A meta-analysis. Psychol Bull. 2016; 142 (3): 291-313.

7. Ferrari PF, Rizzolatti G. New frontiers in mirror neurons research. NY: Oxford University Press, 2015; 408 p.

8. Oberman LM, Hubbard EM, McCleery JP, Altschuler EL, Ramachandran VS, Pineda JA. EEG evidence for mirror neuron dysfunction in autism spectrum disorders. Cognitive Brain Research. 2005; 24 (2): 190-98.

9. Martineau J, Cochin S, Magne R, Barthelemy C. Impaired cortical activation in autistic children: Is the mirror neuron system involved? International Journal of Psychophysiology. 2008; 68 (1): 35-40.

10. Siqi-Liu A, Harris AM, Atkinson AP, Reed CL. Dissociable processing of emotional and neutral body movements revealed by $\mu$-alpha and beta rhythms. Soc Cogn Affect Neurosci. 2018; 13 (12): 1269-79.

11. de Vega M, Padron I, Moreno IZ, García-Marco E, Domínguez A, Marrero $\mathrm{H}$, et al. Both the mirror and the affordance systems might be impaired in adults with high autistic traits. Evidence from EEG mu and beta rhythms. Autism Res. 2019; 12: 1032-42.

12. Binder E, Dovern A, Hesse MD, Ebke M, Karbe H, Saliger J, et al. Lesion evidence for a human mirror neuron system. Cortex. 2017; 90: 125-37.

13. Hobson HM, Bishop DVM. The interpretation of mu suppression as an index of mirror neuron activity: past, present and future. Review R Soc Open Sci. 2017; 4 (3): 160662.

14. Sotoodeh MS, Taheri-Torbati H, Sohrabi M, Ghoshuni M.

Perception of biological motions is preserved in people with autism spectrum disorder: electrophysiological and behavioural evidences. J Intellect Disabil Res. 2019; 63 (1): 72-84.

15. Pineda JA, Carrasco K, Datko $M$, Pillen S, Schalles $M$. Neurofeedback training produces normalization in behavioural and electrophysiological measures of high-functioning autism. Philos Trans R Soc Lond B Biol Sci. 2014; 369 (1644): 20130183

16. Friedrich EVC, Sivanathan A, Lim T, Suttie N, Louchart S, Pillen S, et al. An effective neurofeedback intervention to improve social interactions in children with autism spectrum disorder. J Autism Dev Disord. 2015; 45: 4084-100.

17. Datko M, Pineda JA, Muller RA. Positive effects of neurofeedback on autism symptoms correlate with brain activation during imitation and observation. Eur J Neurosci. 2018; 47 (6): 579-91.

18. Махин С. А., Кайда А. И., Эйсмонт Е. В., Михайлова А. А. Павленко В. Б.; ФГАОУ ВО «Крымский федеральный университет имени В.И. Вернадского», патентообладатель. Способ определения индивидуального частотного диапазона мю-ритма ЭЭГ. Патент РФ № 2702728. 09.10.2019.

19. Simon S, Mukamel R. Power modulation of electroencephalogram $\mathrm{mu}$ and beta frequency depends on perceived level of observed actions. Brain Behav. 2016; 6 (8): e00494.

20. Raymaekers R, Wiersema JR, Roeyers H. EEG study of the mirror neuron system in children with high functioning autism. Brain research. 2009; 1304: 113-21.

21. Kaida Al, Mikhailova AA, Eismont EV, Dzhapparova LL, Pavlenko VB. EEG $\mu$-rhythm reactivity in children during imitation of biological and non-biological motion. [published online ahead of print, 2020.04.16]. Bulletin of RSMU. 2020. DOI: 10.24075/ brsmu.2020.019.

22. Bernier R, Dawson G, Webb S, Murias M. EEG mu rhythm and imitation impairments in individuals with autism spectrum disorder. Brain and Cognition. 2007; 64 (3): 228-37.

23. Pineda JA, Grichanik M, Williams V, Trieu M, Chang H, Keysers C. EEG sensorimotor correlates of translating sounds into actions. Front Neurosci. 2013; 7: 203.

24. Mukamel R, Ekstrom AD, Kaplan J, lacoboni M, Fried I. Singleneuron responses in humans during execution and observation of actions. Current Biology. 2010; 20 (8): 750-56.

25. Кропотов Ю. Д. Количественная ЭЭГ, когнитивные вызванные потенциалы мозга человека и нейротерапия. Донецк: Издатель Заславкий Ю. А., 2010; 506 с.

26. Rizzolatti G, Sinigaglia C. Mirrors in the brain: how our minds share actions and emotions. Oxford University Press, 2008; 242 p. 